\title{
The Trend Analysis of the Availability of Dental Caries and Dental Health Personnel in Indonesia
}

\section{Niniek Lely Pratiwi*}

Humanities Center for Health Policy and Community Empowerment, National Institute of Health Research and Development, Ministry of Health, Jakarta, Indonesia

\begin{abstract}
Background: The behavior of public health in Indonesia in maintaining oral hygiene is low. Lack of awareness about dental health, results in treatment delays at dental health care facilities. This study aims to provide an overview trend of dental caries and dental health personnel in Indonesia.
\end{abstract}

Methods: Data was analyzed from National report on basic health research, RISKESDAS, 2007 and 2013 and the descriptive analysis was made according to the type of data.

Results: The results of the basic health research of community (Riskesdas) for the year 2013 showed that there was an increase in the prevalence of active caries in Indonesian population compared to the year 2007, from $43.4 \%$ (2007) to 53.2\% (2013). Almost all provinces had an increase the prevalence of active caries from 2007 to 2013 , only four provinces (North Maluku, West Papua, Yogyakarta and Riau) experienced a decline. The highest increase was found in the province of South Sulawesi $(29.1 \%)$ and Lampung $(23.6 \%)$, which is 2 times more than the national increase $(9.8 \%)$. The health centers in the provinces of Papua, West Papua and Southeast Sulawesi do not have dental health professionals (dentists/dental nurse) in the percentages of $88.8 \%, 78.7 \%$ and $61 \%$ respectively.

Conclusions: The high prevalence of active caries requires promotion of the importance of prevention of dental caries. Use of toothpaste containing fluoride among different age groups must be implemented. Lack of dental health workers in health centers requires an increase in community development by establishing a cadre of health in order to perform promotion of food consumption behavior with a high fiber content of fruits, vegetables, and calcium so that it becomes a necessity of society.

\section{Keywords: Dental caries; Health workers; Health behavior}

\section{Introduction}

Dental caries is a bacterial disease or infection of the dental hard tissue. The location is very characteristic, and causes progressive damage to the structure of gingiva [1]. The biggest problem today in the field of oral health is a disease of hard tissue of teeth or dental caries in addition to gum disease. Dental caries is an infectious disease and is a progressive demineralization in hard tissue of the tooth surface by organic acids derived from sugar-containing foods [2]. It is most often found in the oral cavity along with periodontal disease. Many factors can lead to dental caries in children. The main factors that cause dental caries are the host (tooth and saliva), the substrate (food), microorganisms that cause caries and time. Dental caries will only be formed when there is interaction between these four factors [3]. Predisposing factors that also have an impact on the occurrence of tooth caries include gender, age, feeding behavior, behavior of cleaning the mouth (brushing teeth, etc.) (Figure 1).

Caries is characterized by the existence of a hole in the hard tissue of teeth, can be brown or black $[4,5]$. Cavities are usually painless until the hole is getting bigger and the innervation of the tooth. At caries get deep enough, usually a common complaint is pain felt by patients when exposed to stimuli like hot, cold, or sweet. If left untreated, caries will increase in size and can reach the pulp chamber, which is a cavity in the tooth that contains nerves and blood vessels. When it reaches the pulp chamber, there will be a process of inflammation that causes throbbing pain. Eventually, a bacterial infection can cause tissue death in the pulp chamber and the infection can spread to the bone tissue supporting the teeth [6].

National report on basic health research, RISKESDAS 2013 showed $53.2 \%$ prevalence of active caries (which are caries that have not been addressed or have not done filling/Decay (D) $>0$ untreated). In Indonesia there are 93,998,727 inhabitants who suffer from active caries [7]. The possibility of a high rate of caries is highly correlated with the pattern of wrong eating habits. Results of epidemiological studies showed people who consume lots of fiber foods tend to reduce the incidence of caries than people who consume soft foods and lots of sugar. According Pratiwi et al. brushing your teeth before going to bed can be very effective in reducing teeth caries [8].

Tooth decay index or Decay, Missing, Filling Teeth (DMFT) Index is tool to measure the level of tooth decay per person. It is an index measuring caries (decay), missing (tooth disconnect indication) and filling (the number of teeth patched). Measurement of the patient's susceptibility to caries can be done by counting the number of cavities, lost or patched. It is still rough because it does not take into account the affected surface caries. This index can be great because of tooth loss due to other causes, especially in older patients, and can be influenced by do treatment patterns [6].

On the other hand, the public perception that dental diseases do not result in death causes a lack of concern for maintaining oral hygiene and dental problems are seated at the last level of the secondary needs. The descriptive analysis results of patient dental caries and the

*Corresponding author: Niniek Lely Pratiwi, Humanities Center for Health Policy and Community Empowerment, National Institute of Health Research and Development, Ministry of Health, Jalan Indrapura 17 Surabaya, and Percetakan Negara 23, Jakarta, Indonesia, Tel: 62 0313528748; E-mail: niniekpratiwi@yahoo.com

Received October 15, 2015; Accepted January 22, 2016; Published January 29 2016

Citation: Pratiwi NL (2016) The Trend Analysis of the Availability of Dental Caries and Dental Health Personnel in Indonesia. Dentistry 6: 360. doi:10.4172/2161 1122.1000360

Copyright: @ 2016 Pratiwi NL. This is an open-access article distributed under the terms of the Creative Commons Attribution License, which permits unrestricted use, distribution, and reproduction in any medium, provided the original author and source are credited. 
Citation: Pratiwi NL (2016) The Trend Analysis of the Availability of Dental Caries and Dental Health Personnel in Indonesia. Dentistry 6: 360. doi:10.4172/2161-1122.1000360

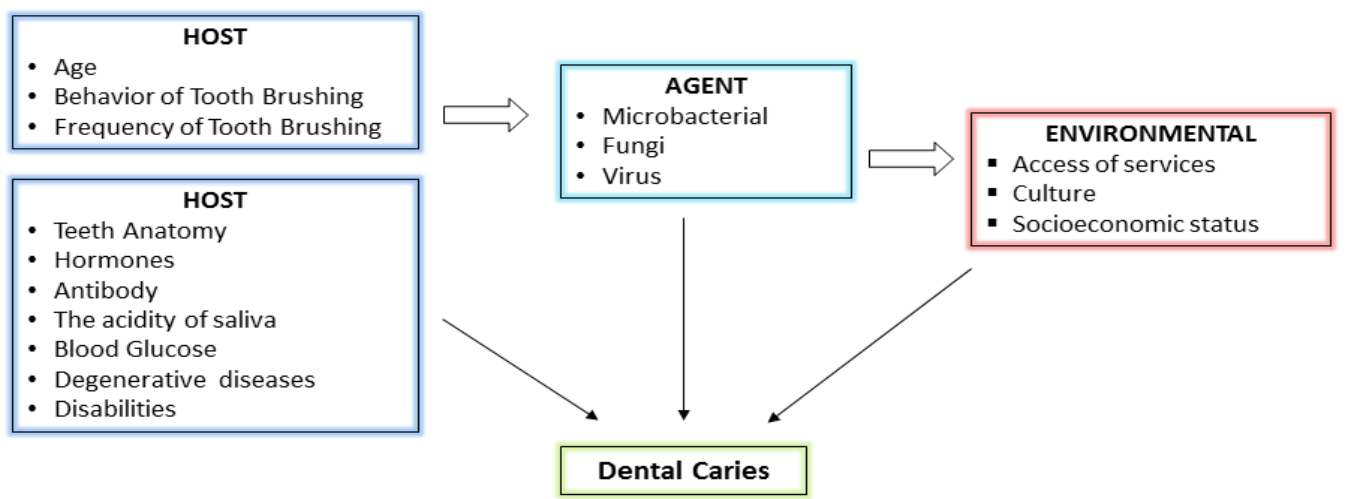

Figure 1: Framework of several variables that can affect the amount of dental caries.

factors in Indonesia was taken from Riskesdas of years 2007-2013 and Media Centre and Agency Center for Information and Data in 2013. According Riskesdas 2013, there is an increase in the prevalence of active caries in the population of Indonesia compared to the year 2007, i.e., from $43.4 \%$ to $53.2 \%$. The increase is in high enough quantities when seen through the eyes of the public health, especially if we convert it into absolute number of Indonesian population. Data estimates of processed data and Information Center (Media Centre) of the Ministry of Health of the population aged 15 years and above amounted to $176,689,336$ inhabitants which is almost half the population. Therefore, the purpose of this study was to analyse the tendency of dental caries in Indonesia and the availability of dental health personnel.

\section{Formulation of the problem}

This study is aimed at answering two important questions namely

a) What is the tendency of dental caries disease in Indonesia?

b) What is the availability of health workers in Indonesia related to dental caries disease?

The results of this study are can de used to develop service programs and preventive measures of oral health community in order to reach the degree of oral health according to WHO expectations. This study is also expected to be able to develop new knowledge for the scientists in Indonesia.

\section{Methods}

\section{Framework analysis}

Many factors that cause pain in the teeth and mouth. Host factors examined included age, method and frequency of tooth brushing. Other host factors that influence the amount of dental caries are the anatomical shape of teeth (with many fissures in the crown will facilitate attachment of leftovers), hormonal factors will affect the degree of acidity in the saliva and the presence of systemic factors such as elevated blood glucose levels will facilitate the occurrence of diseases like periodontitis. These factors along with microbacterial agents such as Streptococcus aureus, S. mutans bacteria found in plaque and debris cause caries and damage the enamel. Presence of fungi in the mucosa of the tongue and gums will lead to the formation of candidiasis in the oral cavity. However, these factors are not investigated. Several environmental factors do not influence our analysis, just as the study of the discussion.

\section{Analysis}

This study used the data from community-based health research rooted in a data base (Riskesdas) in 2007 and 2013. Data of health workers was collected from the Center of Data and Information and National Institute of Business Human Resource Development, Ministry of Health, Republic of Indonesia.

Data analysis was based on the description of the characteristics of:

a) Characteristics: age, how to brush your teeth right is considered nominal data.

b) DMFT Index (data type ratio) Questionnaire: Measurement and inspection dental caries is considered ordinal data

The relationship between the scale of the nominal data with a ratio assuming a normal distribution and put on an ordinal regression analysis and analysed.

\section{Operational definitions of variables}

DMFT Index is an index of oral health that measures the number of cavities (D), the number of teeth has been revoked or disconnect indication (M) and the number of teeth patched (F). It can be determined by a medical examination in the oral cavity and recorded on Dentogram provided on the questionnaire.

\section{Results and Discussion}

\section{Prevalence of caries}

Almost half the population in Indonesia has active dental caries as shown in Table 1 and Figure 2. It indicates that almost all provinces experienced an increase in the prevalence of caries active from 2007 to 2013; only four provinces namely North Maluku, West Papua, Riau and Yogyakarta experienced a decline. The highest increase found in the provinces of South Sulawesi (29.1\%) and Lampung (23.6\%) which more than twice the national increase $(9.8 \%)$. Furthermore, when viewed from the age group (according to WHO) shown in Figure 3, prevalence of patients with active caries also increased from 2007 to 2013, with the biggest increase at the age of 12 years (13.7\%) and 65 years $(14.3 \%)$. While the trend pattern similar gains have the same tendency, namely a decline in the prevalence after the culmination at 44 years.

Figure 4 shows that the drop in the proportion of time to brush teeth properly from 2007 to 2013 occurred in all provinces. A very drastic decline occurred in the province of Riau Islands (15.4\%) and 
Citation: Pratiwi NL (2016) The Trend Analysis of the Availability of Dental Caries and Dental Health Personnel in Indonesia. Dentistry 6: 360. doi:10.4172/2161-1122.1000360

Page 3 of 6

\begin{tabular}{|c|c|c|c|c|}
\hline Province & $2007(\%)$ & $2013(\%)$ & Population aged $>15$ years & Approximate Amount of Caries 2013 \\
\hline West Papua & 40.8 & 37.4 & 557,486 & 208,500 \\
\hline North Maluku & 39.8 & 35.2 & 718,103 & 252,772 \\
\hline Gorontalo & 34 & 48.8 & 754,682 & 368,285 \\
\hline North Sulawesi & 42.9 & 58.5 & 800,638 & 468,373 \\
\hline Maluku & 54.4 & 54.9 & $1,061,677$ & 582,861 \\
\hline Bengkulu & 34.8 & 49.3 & $1,249,238$ & 615,874 \\
\hline Babel & 50.8 & 66.7 & 944,839 & 630,208 \\
\hline Kepri & 39.6 & 58.2 & $1,368,920$ & 796,711 \\
\hline Sultra & 44 & 52.6 & $1,539,436$ & 809,743 \\
\hline North Sulawesi & 47.4 & 57 & $1,698,831$ & 968,334 \\
\hline Central Kalimantan & 49.4 & 62.1 & $1,608,217$ & 998,703 \\
\hline West Nusa Tenggara (NTB) & 30.8 & 31.3 & $3,202,734$ & $1,002,456$ \\
\hline Papua & 40.3 & 50.3 & $2,148,954$ & $1,080,924$ \\
\hline Central Sulawesi & 48 & 59.3 & $1,861,021$ & $1,103,585$ \\
\hline Bali & 37.6 & 39.8 & $3,068,044$ & $1,221,082$ \\
\hline DI Yogyakarta & 52.3 & 50.5 & $2,777,211$ & $1,402,492$ \\
\hline Nusa East Tenggara (NTT) & 40.7 & 48.3 & $3,116,580$ & $1,505,308$ \\
\hline Aceh & 41 & 47.7 & $3,177,085$ & $1,515,470$ \\
\hline Jambi & 56.1 & 66.1 & $2,312,659$ & $1,528,668$ \\
\hline East Kalimantan & 49.6 & 63.3 & $2,753,491$ & $1,742,960$ \\
\hline North Sumatera & 41.6 & 51.3 & $3,427,772$ & $1,758,447$ \\
\hline South Kalimantan & 50.7 & 66 & $2,722,366$ & $1,796,762$ \\
\hline Riau & 53.3 & 51.9 & $4,107,117$ & $2,131,594$ \\
\hline West Kalimantan & 55.2 & 71.7 & $3,072,565$ & $2,203,029$ \\
\hline DKI Jakarta & 40.6 & 42.6 & $7,609,272$ & $3,241,550$ \\
\hline South Sumatera & 43.9 & 60.2 & $5,479,724$ & $3,298,794$ \\
\hline Lampung & 43.1 & 66.7 & $5,560,440$ & $3,708,813$ \\
\hline South Sulawesi & 37.6 & 66.7 & $5,738,932$ & $3,827,868$ \\
\hline North Sumatera & 40.1 & 46.6 & $8,939,623$ & $4,165,864$ \\
\hline Banten & 37.3 & 53.9 & $8,074,025$ & $4,351,899$ \\
\hline Central Jawa & 43.1 & 47.6 & $24,089,433$ & $11,466,570$ \\
\hline East Jawa & 47.8 & 50.8 & $28,855,895$ & $14,658,795$ \\
\hline North Jawa & 39 & 57.2 & $32,162,328$ & $18,396,852$ \\
\hline Indonesia & 43.4 & 53.2 & $176,689,336$ & $93,998,727$ \\
\hline
\end{tabular}

Table 1: Distribution of the number of patients with active caries by Province, 2013.

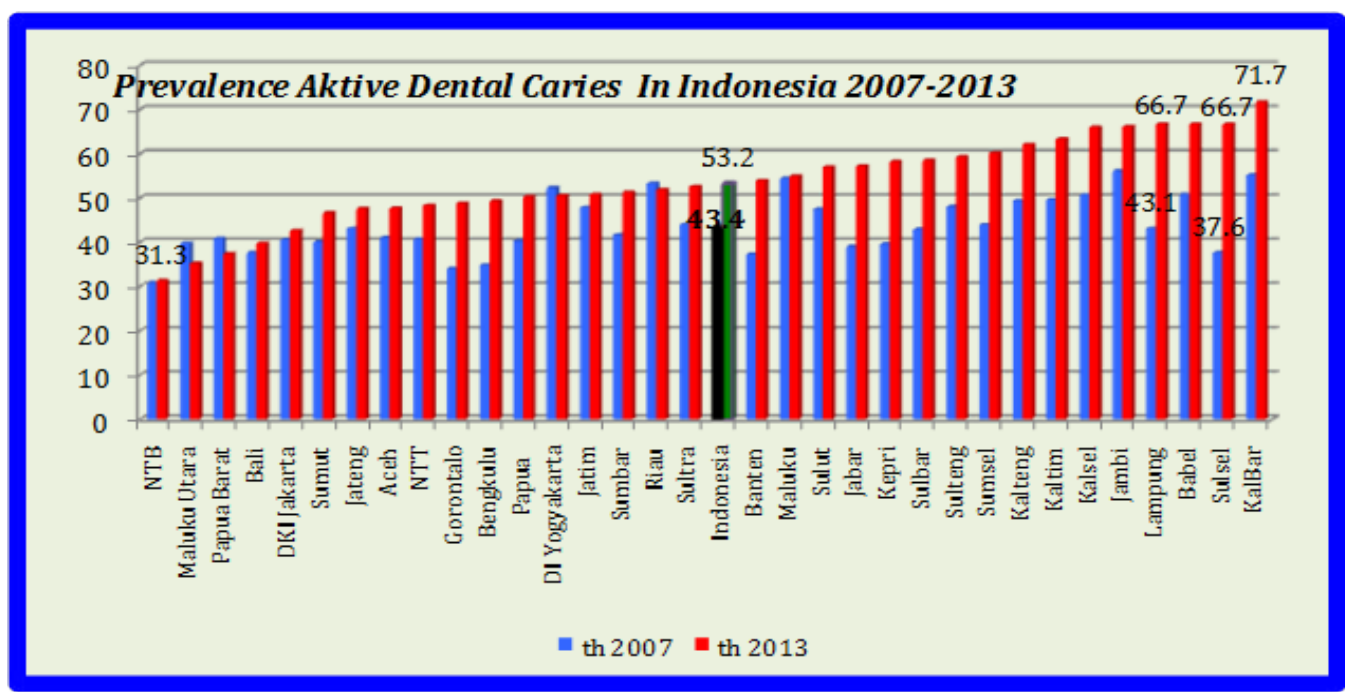

Figure 2: Prevalence of active caries in Indonesia, 2007-2013. 
Citation: Pratiwi NL (2016) The Trend Analysis of the Availability of Dental Caries and Dental Health Personnel in Indonesia. Dentistry 6: 360. doi:10.4172/2161-1122.1000360

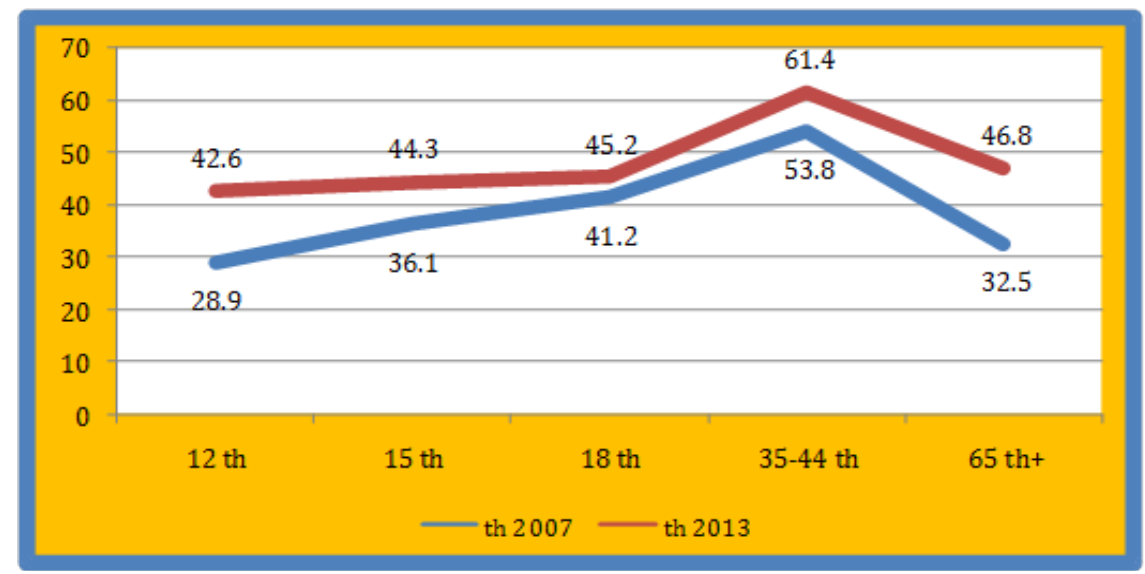

Figure 3: The prevalence of active caries based on age-group in Indonesia, 2007-2013.

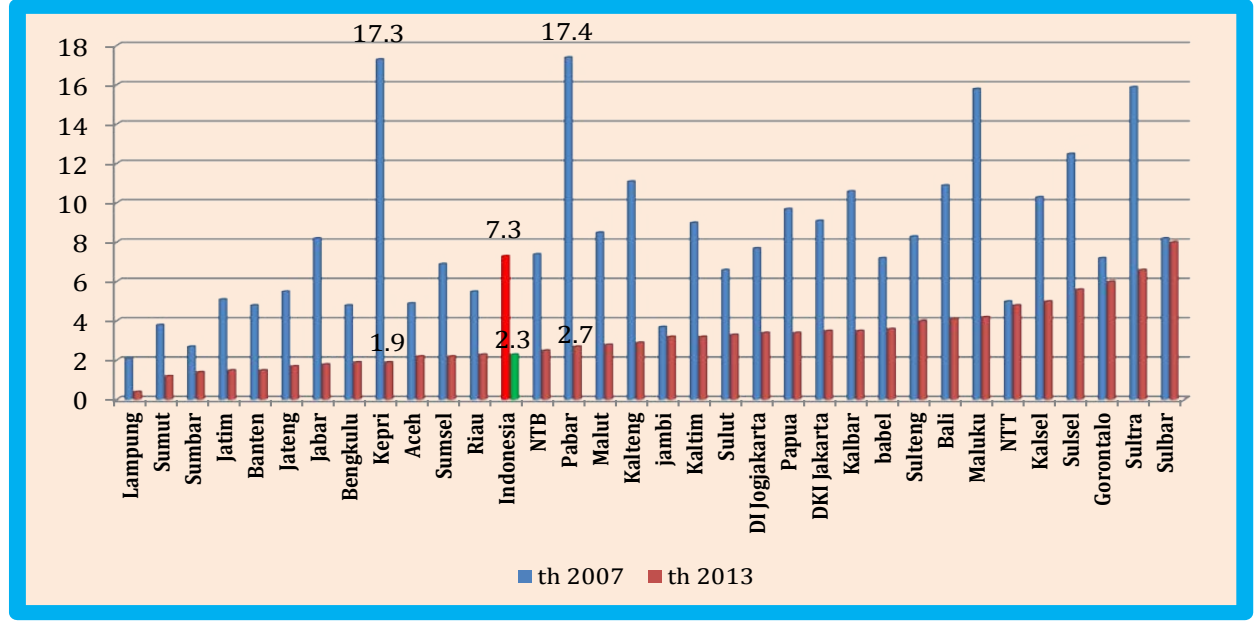

Figure 4: Proportion tooth brushing at the right time, in Indonesia.

the Province of West Papua (14.7\%) in the amount of 3-4 times that of the national proportion (5\%). Such situation is a serious challenge for peer health promotion or dentist, in promoting oral health in the community. There is an increase in the amount of people brushing their teeth every day of the year 2007 of $91.1 \%$ to $93.8 \%$ in 2013 . In terms of how to brush teeth properly turned out to be other than a small proportion, also decreased, namely from the year 2007 amounted to $7.3 \%$ to $2.3 \%$ in 2013 . It indicates $91.5 \%$ (about 161 million) of people brush their teeth every day the wrong way.

\section{Dentists in health centers}

Based on the analysis of 2013 data from Information Center (Media Centre), Ministry of Health and the Central Bureau of Human Resources business (BPPSDM) we conducted a simple analysis to look at the distribution level health workers in health centers. Dentist criteria taken are less, if there are no dentists in health centers. If there is one person in health centers and more, if there is more than one dentist in health center. The results of the analysis showed that most health centers in 33 provinces there are 'less' power dentist. 3 provinces West Papua, Papua and North Sulawesi have the conditions 'less' to the maximum. In these 3 provinces, more than $80 \%$ of health centers have 1 or no dental health professional. Conversely 3 provinces that have a health center 'excess' i.e., more than adequate number of dentists are Bali, Yogyakarta and Riau Islands. In these provinces more than $40 \%$ of public health centers have more than 1 dentist.

Furthermore, if the role is carried out by dental nurses, one of the workers can be referred to the health center as dental health workers. Figure 5 shows the adequacy of dental health workers (dentist/dental nurse) at health centers by province. The number of health centers that do not have dental health workers is highest in the provinces of Papua, West Papua and East Sulawesi in $88.8 \%, 78.7 \%$ and $61 \%$ respectively. Conversely health centers that have an excess of dental health workers is highest in the provinces of DI Yogyakarta, Riau Islands and Bali in $98.3 \%, 91.3 \%$ and $87.3 \%$ respectively. Other provinces have moderate number of dental health workers in health centers.

We compare some of the above conditions between the prevalence of active caries (as outcome), correct tooth brushing behavior (obstacle), the adequacy of dental health personnel (risk factors) by taking a few provinces of West Papua, Riau Islands, DI Yogyakarta as an example.

\section{Yogyakarta province}

98.3\% health centers have excess dental health workers (dentists/ dental nurse) and no shortage, but the number of people with proper 
Citation: Pratiwi NL (2016) The Trend Analysis of the Availability of Dental Caries and Dental Health Personnel in Indonesia. Dentistry 6: 360. doi:10.4172/2161-1122.1000360

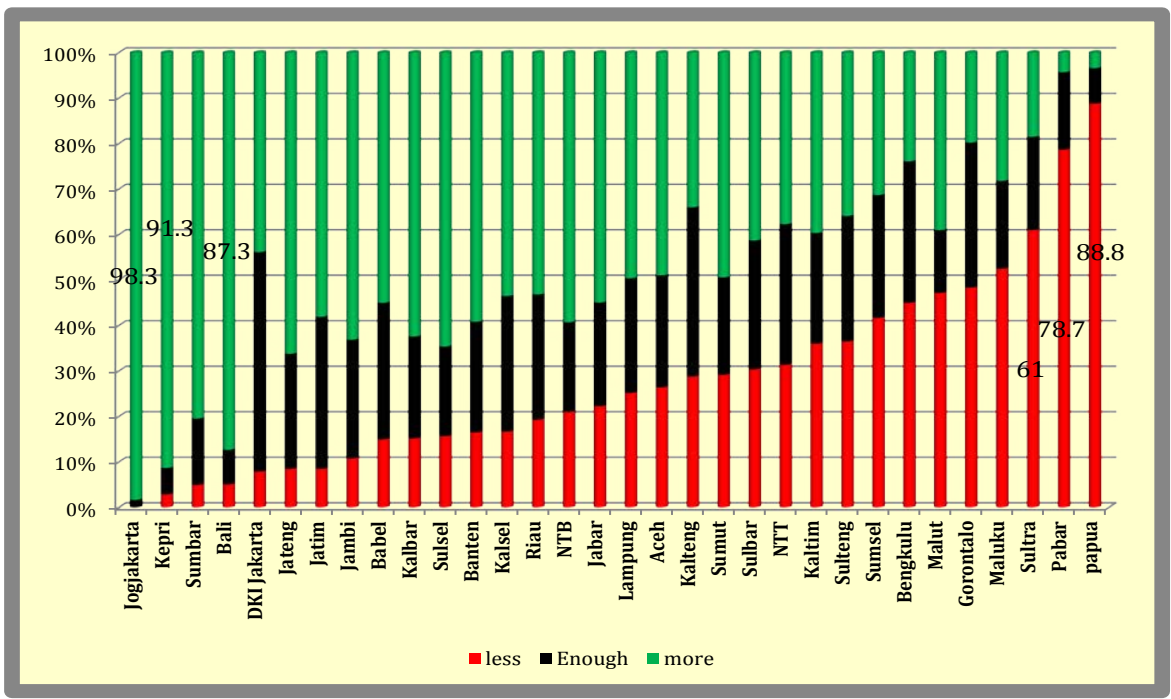

Figure 5: Availability of dentists in health centers by province in Indonesia, 2013.

tooth brushing behavior is quite small and there is a decrease from 2007 to 2013 ( $7.7 \%$ to $3.4 \%$ ). This condition is certainly a phenomenon that is quite contradictory.

The interesting points in the analysis are:

- Why the province with the excess number of dental health workers in health centers has only $7.7 \%$ people who are able to properly brush their teeth and a there is a decline in the correct way to brush teeth in society?

- There is a decline in the prevalence of active dental caries from $52.3 \%$ in 2007 to $50.5 \%$ in 2013 , but this decrease was less significant compared to existing human resources in the health centers. Especially if people who suffer from active dental caries converted in absolute terms, there are $1,402,492$ active caries in total.

\section{Riau Islands province}

91.3\% public health centers have excess dental health professionals (dentists/dental nurse) and only a few health centers that lack, but the proportion of people who properly brush their teeth has seen a 'free fall' of $17.3 \%$ (2007) to $1.9 \%$ (year 2013), let alone the proportion is quite small. Even this condition would be highly contradictory phenomenon. However, these conditions have an astounding impact with increased prevalence of active caries from $39.6 \%$ to $58.2 \%$. There is a need for study in the provinces with dental health resources in health centers redundant, even a decline in the behavior of how to brush their teeth properly and increasing cases of active caries at $18.6 \%$. When there is an excess of dental health professionals, it is not necessary to have 796,711 inhabitants estimated to suffer from active caries. Public awareness about the importance of oral hygiene is lacking. Health professionals need to actively provide efforts for improving public dental health.

\section{West papua}

In $88.8 \%$ public health centers, there is a shortage or no dental health workers in West Papua. The proportion of people with proper tooth brushing behavior has decreased from $17.4 \%$ in 2007 to $2.7 \%$ in 2013 and the number is quite small. Even this condition would be a very interesting phenomenon though not contradictory. There is decrease in the prevalence of active caries from $40.8 \%$ to $37.4 \%$.
When compared to the two provinces explained above when there is a shortage of health professionals in the dental clinic the prevalence of active caries reduced only $3.4 \%$ ? Are there other factors involved? About 208,500 inhabitants are estimated to suffer from active caries. Based on the above data analysis seems possible factors for behavior of the people of West Papua are diet that is low in sugar, lots of calcium intake and high fiber foods. Proper tooth brushing etiquette may also be a reason [8].

Many oral hygiene factors are closely related to caries. They include sugary diet, degenerative disease and genetic factors. Excessive sugar consumption leads to an increased risk of obesity which in turn increases the risk of diabetes mellitus. It increases the risk of dental caries or periodontitis disease. Saliva balances the acidic environment in the mouth. Conditions like Sjögren's syndrome, diabetes mellitus, diabetes insipidus, sarcoidosis and medications such as antihistamines and antidepressants can affect the production of saliva. Radiation therapy to the head and neck can damage cells in the salivary glands [5].

Good oral hygiene practice is required to minimize the diseasecausing agents and disposal of dental plaque in the mouth. The plaque contains bacteria. Caries can be prevented with regular dental cleaning and examination. For dental health, sugar consumption is important to note. The excess sugar in the mouth leads to production of acids by bacteria which damage the tooth surface $[9,10]$. Knowledge of cleaning the teeth and mouth before bedtime needs to be disseminated to the public given that the increase in knowledge is a stimulus to improve attitude, which at a certain period becomes the culture of certain groups of people and can be a subjective norm so that it can be perceived by society and become the controlling behavior for the surrounding community [11]. Changes in behavior takes time and therefore can be modified with behavioral therapy approach. The government can also facilitate the improvement of dental health infrastructure that includes enabling factors, predisposing and reinforcing factors or health belief models with emphasis on the threat posed by the risk of dental and oral diseases in other organs as a focal infection $[12,13]$.

According to the analysis from Figure 5 there is a possibility of low public awareness of dental health issues in the three provinces 
Citation: Pratiwi NL (2016) The Trend Analysis of the Availability of Dental Caries and Dental Health Personnel in Indonesia. Dentistry 6: 360. doi:10.4172/2161-1122.1000360

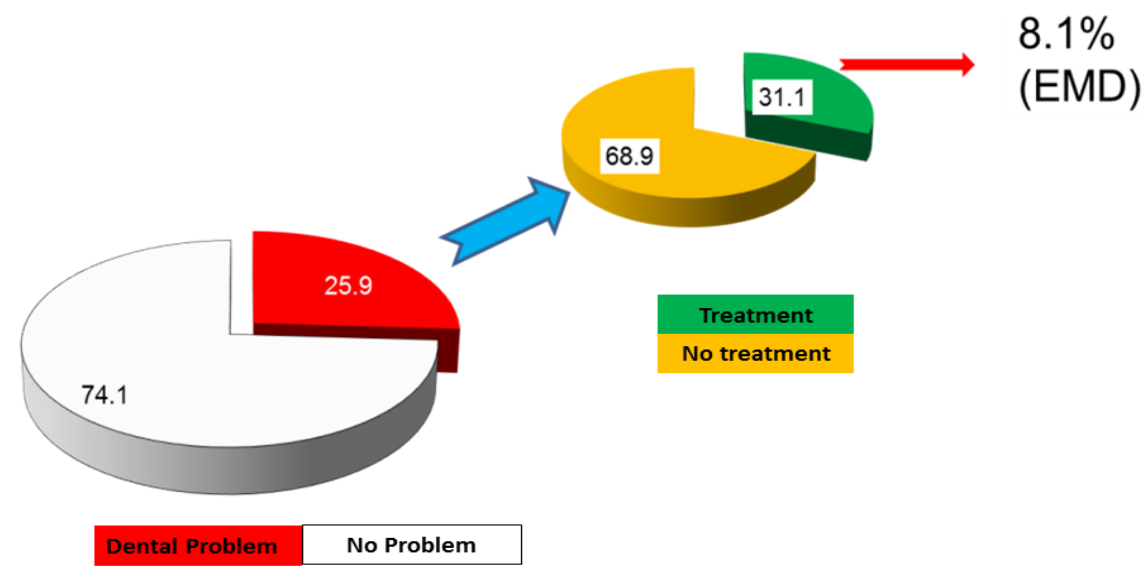

Figure 6: The proportion of people of all ages with problematic teeth and mouth and received treatment, and EMD in Indonesia, 2013.

explained above both from the peers themselves dental health workers or health workers even more.

Effective Medical Demand (EMD) is defined as the percentage of people who have problems with the teeth and mouth in the last 12 months multiplied with the percentage of people who receive care or dental treatment from medical personnel. Based on interviews of $25.9 \%$ of the Indonesian population having oral and dental problems in the last 12 months (potential demand), $31.1 \%$ of people among them are receiving care and treatment from medical personnel (dental nurse, dentist or dental specialist), while $68.9 \%$ do not care. Overall affordability to get dental care from medical personnel/EMD is only $8.1 \%$ (Figure 6).

\section{Conclusion}

Almost all provinces in Indonesia have an increased prevalence of active dental caries. The highest prevalence was found in the provinces of South Sulawesi $(29.1 \%)$ and Lampung (23.6\%). The prevalence of patients with active caries was highest at the age of 12 years $(13.7 \%)$ and 65 years $(14.3 \%)$. A decrease in the proportion of people brushing their teeth properly from 2007 to 2013 occurred in all provinces. A very drastic decline occurred in the provinces of Riau Islands (15.4\%) and West Papua (14.7\%) in the amount of 3-4 times that of the national proportion (5\%). Such situation is a serious challenge for peer health promotion.

The amount of health centers that do not have dental health workers is highest in the provinces of Papua, West Papua and East Sulawesi in $88.8 \%, 78.7 \%$ and $61 \%$ respectively. Conversely health centers that have an excess of dental health workers is highest in the provinces of DI Yogyakarta, Riau Islands and Bali in 98.3\%, 91.3\% and $87.3 \%$ respectively. Other provinces have moderate number of dental health workers in health centers.

Many factors contribute to the increase of dental caries. They include lack of public awareness about dental hygiene and access dental health services, availability of healthy teeth, eating patterns and consumption habits and genetic factors. The adequacy of health workers is not directly proportional to the prevalence of active dental caries.

\section{Recommendations}

Dental health professionals need to actively provide efforts for improving public dental health and need innovative efforts for dental health personnel so that people rely more in maintaining dental health and oral hygiene. There is a need to empower communities to become agents of change from community leaders in providing preventive measures, dental health promotion and the importance of maintaining oral hygiene.

\section{References}

1. Finn SB (1999) Epidemiology of Dental Caries. In: Clinical Pedodontics. (4thedn), WB Saunders Company, Philadelphia.

2. Spolsky V (2002) Epidemiology of Gingival and periodontal diseases. In Carranza's Clinical Periodontology. (9thedn), WB Saunders Company, New York.

3. Goldman HM, Schluger S, Fox L, Cohen DW (2006) Periodontal therapy (9thedn), CV Mosby Company, St Louis.

4. Baehni PC, B. Guggenheim B (1996) Potential of diagnostic microbiology for treatment and prognosis of dental caries and periodontal diseases. Crit Rev Oral Biol Med 7: 259-277.

5. Bots CP, Brand HS, Veerman EC, van Amerongen BM, Nieuw Amerongen AV (2004) Preferences and saliva stimulation of eight different chewing gums. In Dent J 54: 143-148.

6. Directorate General of Health Community (2006) Planning Guidelines Leve Health Center. Ministry of Health, Republic of Indonesia, Jakarta.

7. Ministry of Health and National Institute of Health Research and Development (2013) National report on basic health research, RISKESDAS, 2013. Jakarta, Indonesia, 2014 (and additional analysis). Ministry of Health, Republic of Indonesia, Jakarta.

8. Pratiwi NL, Basuki $\mathrm{H}$, Agus S (2009) Oral hygiene behavior relationship, the economic and social, cultural smoking, access to the amount of Health Services DMFT index. Health Systems Research Bulletin 12: 85-96.

9. Anderson T (2004) Dental treatment in Medieval England. Br Dent J 197: 419425 .

10. Ash MM Jr., Nelson SJ (2003) Wheeler's Dental Anatomy, Physiology, and Occlusion. ( $8^{\text {th }}$ edn), Saunders, St. Louis.

11. Glanz K, Lewis FM, Rimer BK (1997) Health Behavior and Health Education: Theory, Research, and Practice. (2ndedn), Jossey-Bass Inc., San Francisco.

12. Green LW, Kreuter MW (1999) Health Promotion Planning: An Educational and Environmental Approach. ( ${ }^{\text {nd }}$ edn), Mayfield Publishing Company, Mountain View.

13. Mausner JS, Kramer S (1985) Epidemiology: An Introductory Text (2ndedn), WB Saunders Company, Philadelphia. 